\title{
Døgnbehandling ved dobbeltdiagnose
}

\author{
Det er urealistisk å forvente stabil motivasjon for endring hos pasienter med dobbeltdiagnose. De må få hjelp \\ med den psykiske lidelsen selv om de fortsetter å ruse seg, eller ruslidelsen selv om de vegrer seg mot \\ annen behandling. Derfor skriver vi aldri ut pasienter som ruser seg under oppholdet på vår døgnavdeling.
}

Pasienter med både alvorlig psykisk lidelse og rusmiddelproblemer, særlig dem med omfattende funksjonsproblemer, har lenge hatt et særlig utilfredsstillende hjelpetilbud. Denne erkjennelsen resulterte $i$ etableringen en tverrfaglig enhet for dobbeltdiagnose ved Distriktspsykiatrisk senter Vinderen i Oslo i 2007, den hittil eneste dobbeltdiagnoseavdeling ved et distriktspsykiatrisk senter.

\section{Dobbeltdiagnose}

Dobbeltdiagnosebegrepet viser til samtidig rusmiddelproblemer og alvorlige psykiske lidelser, spesielt schizofreni og bipolare lidelser med psykotiske symptomer. Begrepet «sammensatte lidelser» er trolig mer dekkende, da pasientene ofte sliter med angst og depresjon og har store yrkesmessige, sosiale, økonomiske og boligmessige vansker, og kan ha somatiske lidelser. Kombinasjonen psykisk lidelse og rus har negative følger for forløp og effekt av behandling, med høy risiko for frafall, stadige innleggelser på akuttavdelinger, økt risiko for suicid og alvorlige infeksjoner, forverring av psykose, depresjon og annen psykopatologi, foruten økt rusmiddelbruk. Pasientene faller lett ut av poliklinisk behandling og har lavere etterlevelse ved medikamentell behandling enn pasienter med bare psykoselidelse $(1,2)$.

Flere behandlingsstudier fra andre land viser at effektiv behandling for disse pasientgruppene omfatter tiltak basert på kognitive og atferdsmessige prinsipper og integrert behandling av psykiske lidelser og rusmiddelavhengighet (3). Slike tiltak kombineres gjerne med oppdatert og kvalitetssikret medikamentell behandling og substitusjonsbehandling.

\section{Behandlingsmodellen}

Tverrfaglig enhet for dobbeltdiagnose på Vinderen har 12 sengeplasser. Pasientene søkes inn fra primær- og spesialisthelsetjenesten til frivillig eller tvungent psykisk helsevern. De som er vanskeligst å nå gjennom andre behandlingstilbud, prioriteres.

Behandlingsmodellen er såkalt integrert dobbeltdiagnosebehandling, som i dag har best forskningsmessig kunnskapsgrunnlag $(2,4)$. Dette innebærer at pasienten mottar et sammenhengende behandlingstilbud fra oppsøkende kontaktetablering, via avrusning, utredning og behandling, til etablering $i$ varige botilbud i samarbeid med det kommunale hjelpeapparatet. Enheten tilbyr avgiftning, stabilisering, tverrfaglig utred- ning og individuell og integrert behandling, det vil si samtidige tiltak for rusmiddellidelse og psykisk lidelse. Sentralt står kognitiv miljøterapi (5), med elementer av motiverende intervju (6), og medikamentell behandling, eventuelt substitusjonsbehandling samt strukturert fysisk aktivitet som fremmer mestring og gode opplevelser for pasientene. Vi etterspør pasientens mål og hjelper til med å utarbeide en kognitiv behandlingsplan. Pasienten får utlevert en informasjonsperm om kognitiv miljøterapi. Behandlingsmiljøet er lagt til rette for at pasienten skal lære seg tenkemåter, ferdigheter og verktøy som kan hjelpe ham/henne til å håndtere problemer som depresjon, angst, psykotiske symptomer, rusmiddelavhengighet og søvnvansker og oppnå viktige mål.

\section{Pasientene}

Mer enn tre firedeler av pasientene er bostedsløse når de kommer til enheten, og alle har omfattende rusavhengighet. De fleste bruker flere illegale stoffer vanligst er blandingsmisbruk med amfetamin, hasj, benzodiazepiner og alkohol, og om lag halvparten bruker også opiater. Mange pasienter blir skrevet ut med en psykoselidelse. To tredeler er menn, og snittalderen er 30 år (ramme 1). Gjennomsnittlig liggetid er tre måneder.

Mange pasienter trenger mye tid og en utradisjonell tilnærming for å klare å ta imot et tilbud, men det er sjelden de avslår et tilbud fra oss. Det er vanlig at pasientene ikke klarer å komme den dagen de skal, og mange er påvirket av rusmidler når de først kommer. Vi sanksjonerer ikke, men kan -

\section{Ramme 1}

\section{Mann som sluttet å snakke}

Einar, rundt 30 år, har de siste årene bodd i lavterskeltiltak for personer med rusmiddelproblemer, uten fast bopel. Livet hans har vært preget av intenst rusmisbruk, og det har vært mange episoder med bisarr atferd og uro. Han har fremstått som tankeforstyrret og med konstant usammenhengende tale. Det har vært vanskelig å forstå ham, og det er usikkert hva han har forstått av hva andre har sagt til ham. Hans evne til egenomsorg var fraværende, for eksempel gikk han ut vinterstid i sokkelesten.

Einar ble tvangsinnlagt på en akuttpsykiatrisk avdeling en høst for noen få år siden. Han var da psykotisk og ble overført til en avdeling for langtidsbehandling fordi tverrfaglig enhet for dobbeltdiagnose ikke hadde plass til ham. Han ble så overført til oss noen måneder senere. Han hadde forsøkt å ha utgang mens han var i langtidsavdelingen og hadde uten unntak kommet tilbake etter å ha inntatt rusmidler. Han var fortsatt psykotisk da han kom til oss, til tross for adekvat antipsykotisk medikasjon i to måneder. Han sa lite og hadde gjennomgående lang latenstid før han svarte på henvendelser.

I den kognitive miljøterapien ble det lagt vekt på atferdsmessige intervensjoner, med skrevne ukeplaner, positiv forsterkning og stimulering av ønsket atferd. Han slet med sosial angst, som ble forsterket av lav selvfølelse og tankeforstyrrelser. Han trengte tydelig bekreftelse på sine kvaliteter som menneske og oppmuntring og veiledning for å håndtere sosiale situasjoner. Det var avgjørende at han etter hvert følte eierskap til sin behandling, og han fattet håp om at endring var mulig. Han så et alternativer til en fortvilet livssituasjon.

I løpet av vinteren bleknet de psykotiske symptomene, og Einar ble overført til frivillig behandling. Han deltok nå aktivt i enhetens aktiviteter. Han hadde utgang de siste månedene, var pålitelig og etterrettelig, viste god egenomsorg, og fulgte opp både egne planer og oppgaver han ble satt til på en samvittighetsfull måte. Kontakten og tillitsforholdet til foreldre ble styrket gjennom systematisk pårørendearbeid, og han gjenopprettet kontakten med familien.

Einar hadde et $\varnothing n s k e$ om arbeid, begynte med arbeidstrening i en kafé. Han gjorde arbeidsoppgavene han ble satt til på en skikkelig måte, men strevde med å snakke med andre. De største endringene kunne ses i hans evne til mimikk, blikkontakt og forståelse for humor.

Einar hadde sporadisk drukket litt $\varnothing \mathrm{l} ø \varnothing \mathrm{r}$ han kom tilbake til posten og fortalte dette selv umiddelbart, men misbrukte ikke illegale rusmidler. Einar ble skrevet ut til en botreningsenhet for pasienter med psykiske lidelser. Det ble raskt åpenbart at han strevde med alminnelige daglige aktiviteter. Han kjøpte øl i butikken, men ikke mat, og måtte få trening i hvordan han skulle gå frem for å gjøre dette. Han trengte altså litt mer tid på tverrfaglig enhet for dobbeltdiagnose. Etter tre uker flyttet han tilbake til botreningsenheten med mål om egen varig bolig. Det siste året har han gått på arbeid daglig og er i ferd med å flytte inn i egen bolig. 
for å skåne pasienten og for å beskytte de andre pasientene - skjerme pasienten dersom han/hun er svært psykisk ustabil eller ruset. Det tas urinprøver for å få informasjon om rusmiddelbruk («Det er lurt å vite hva du har tatt») eller for å skape motivasjon («Nå er det tre uker siden du har hatt positive prøver»). Pasientene er informert om at de ikke får være i miljøet når de er ruspåvirket og at det er personalet som bestemmer når de er det.

Vi tar alltid godt imot pasienter som har vært ute og kommer tilbake til enheten etter å ha ruset seg - når som helst og med tilbud om transport tilbake til avdelingen. Når vi ikke truer med utskrivning, gjør heller ikke pasientene det. Svært få av pasientene skriver seg selv ut fra enheten mot vårt råd.

I samarbeid med pasienten utarbeides behandlingsplan med mål og delmål som endres underveis. Alle pasienter har sin egen behandlingsplan og sine egne regler i avdelingen. Avdelingen skal stå for strukturen som skal danne basis for behandlingsplan og mål. Døgnrytme og måltider kan være et problem i starten. Behandlingen omfatter strukturerende aktiviteter, individuelle terapisamtaler, gruppetilbud, undervisning og fysisk aktivitet.

Vi forsøker å få til gradvise utskrivninger hvor tjenester avvikles samtidig som det nye tilbudet der pasienten skal bo, bygges opp. Det etableres nye relasjoner mens pasienten fortsatt er innlagt. Mye av denne aktiviteten foregår utenfor enheten. Enkelte pasienter har fortsatt å gå på arbeid mens de har vært innlagt.

Vi skriver ikke ut pasienter til lavterskeltiltak som væresteder og hybelhus, og det er et stort behov for tilrettelagte og varige boliger. Vi har for tiden et toårig prosjekt, finansiert av Husbanken og Regionalt kom- petansesenter for dobbeltdiagnose rus og psykiatri, for å finne bedre løsninger (7).

Vi ser ikke på reinnleggelser som noe nederlag, men som en del av pasientens endringsprosess. Vi tilbyr planlagte korte reinnleggelser for særlig sårbare pasienter og i noen tilfeller en reservert kriseplass for pasienter en tid etter utskrivningen.

\section{Motivasjon ingen forutsetning}

Utgangspunktet for behandling av pasienter med dobbeltdiagnose er at det er urealistisk å forvente stabil motivasjon for endring. Motivasjonen kommer og går og må kontinuerlig arbeides med ved å belyse, akseptere, trøste og oppmuntre. Pasienten kan miste motet, men det kan ikke vi som helsepersonell gjøre. Vi kan ikke forvente at pasienter som har så omfattende problemer og som tidligere har opplevd så mange skuffelser og nederlag, skal være motiverte for å gjøre endringer i sine liv. Både fra et faglig og etisk ståsted er vi uenige $i$ det syn at disse personene blir mer motiverte om de får «gå en runde til». Ingen får det bedre av å ha det verre først.

Vår erfaring er at den motivasjonen pasientene klarer å gi uttrykk for ved inntak er en dårlig prediktor for hvor vellykket behandlingen faktisk blir. Dessuten opplever vi ofte at motivasjonen først kommer når pasienten er avgiftet og stabilisert. Selvsagt svinger det, og tilbakeskritt skjer, men det er vi forberedt på. Derfor skriver vi aldri ut pasienter fordi de ruser seg under oppholdet.

Disse pasientene må få hjelp når de er mottakelige for det. Hjelpeapparatet må bidra til å gjøre pasientene motiverte, få dem til å erfare at alt ikke er håpløst og til å se mulighetene. Vi kan ikke etterspørre deres motivasjon og ekskludere dem fra behandling fordi de «ikke er motiverte nok». Pasientene må få hjelp med den psykiske lidelsen, selv om de fortsetter å ruse seg, eller med ruslidelsen selv om de vegrer seg mot annen behandling. Når pasientene får noe hjelp og merker at det nytter, tar de gjerne imot mer.

Grete Jorunn Sølvberg Larsen

grete.larsen@diakonsyk.no

Torkil Berge

Distriktspsykiatrisk senter Vinderen

Diakonhjemmet Sykehus

Postboks 85 Vinderen

0319 Oslo

Pasienten har gitt samtykke til at artikkelen blir publisert.

Oppgitte interessekonflikter: Ingen

\section{Litteratur}

1. Gråwe RW, Hagen R. Kombinert rusmiddelavhengighet og alvorlige psykoselidelser. I: Berge T. Repål A, red. Håndbok i kognitiv terapi. Oslo: Gyldendal Akademisk, 2008: 513-51.

2. Mueser KT, Noordsy DL, Drake RE et al. Integrert behandling av rusproblemer og psykiske lidelser. Oslo: Universitetsforlaget, 2006.

3. Kavanagh DJ, Mueser KT. Current evidence on integrated treatment for serious mental disorder and substance misuse. Tidsskrift for Norsk Psykologforening 2008: 44: 618-37.

4. Drake RE, Neal EL, Wallach MA. A systematic review of psychosocial research on psychosocial interventions for people with co-occurring severe mental and substance use disorders. J Substance Abuse Treatment 2008; 34: 123-38.

5. Oestrich IH, Holm L. Kognitiv miljøterapi. At skabe et behandlingsmiljø i ligeværdigt samarbejde. 2. utg. København: Dansk Psykologisk Forlag, 2006

6. Miller WR, Rollnick S. Motivational interviewing. Preparing people for change. New York, NY: Guilford Press, 2002.

7. Karagøz EMN. «Hvor lenge skal han bo på TEDD?» Forståelse av bostedsløshet - kontra retten til en egen bolig, et hjem. Tidsskrift for psykisk helsearbeid 2009; 7 : 17-25

Mottatt 3.10. 2010, første revisjon innsendt 27.11. 2010, godkjent 24.2.2011. Medisinsk redaktør Petter Gjersvik. 